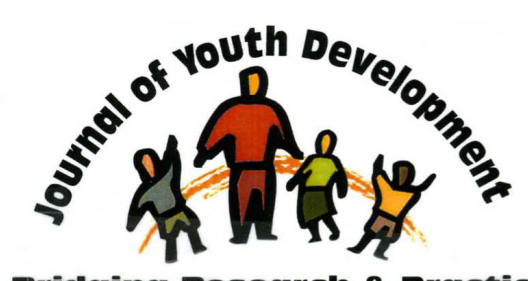

Bridging Research \& Practice

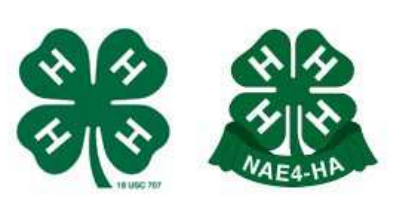

\title{
Cacophony and Change in Youth After School Activities: Findings from the 4-H Study of Positive Youth Development
}

\author{
Christina Theokas Ph.D. \\ Post-Doctoral Fellow \\ Institute for Applied Research in Youth Development \\ Tufts University \\ Medford, MA \\ christina.theokas@tufts.edu \\ Jacqueline V. Lerner, Ph.D. \\ Professor of Applied Developmental and Educational Psychology \\ Boston College Lynch School of Education \\ Chestnut Hill, MA \\ Erin Phelps Ed.D. \\ Research Director \\ Institute for Applied Research in Youth Development \\ Tufts University \\ Medford, MA \\ erin.phelps@tufts.edu \\ Richard M. Lerner Ph.D. \\ Bergstrom Chair in Applied Developmental Science \\ Institute for Applied Research in Youth Development \\ Tufts University \\ Medford, MA \\ richard.lerner@tufts.edu
}




\title{
JOURNAL OF YOUTH DEVELOPMENT \\ bridging research and practice
}

\section{Cacophony and Change in Youth After School Activities: Findings from the 4-H Study of Positive Youth Development}

\author{
Christina Theokas, Erin Phelps and Richard Lerner \\ Tufts University \\ Jacqueline V. Lerner \\ Boston Collete
}

\begin{abstract}
This paper describes the configuration and changes in young adolescents' participation in structured after school activities. Using data from the 4-H Study of Positive Youth Development the 983 youth studied in both the first and the second waves of this research (fifth and sixth grade, respectively) were found to engage in structured after school activities at high levels. Fewer than $12 \%$ did not participate in any activities. Participation in multiple activities was the norm for these youth and the configuration of activities changed between grades. The breadth of participation in structured after school activities suggests, first, that it would be ideal to have broad community collaboration in regard to youth programming to ensure that youth receive excellent programming, no matter where they turn; and, second, that youth development researchers and practitioners need to consider new approaches to conceptualizing and evaluating the possible role of any one after-school program in promoting exemplary development.
\end{abstract}

\section{Introduction}

Previous research has demonstrated that youth involvement in structured activities after school can be a productive use of time, and as well can positively impact academic achievement, selfesteem, civic engagement, and relationships with others (Cooper, Valentine, Nye \& Lindsay, 1999; Eccles \& Barber, 1999; Youniss \& Yates, 1997). However, research has typically examined a single program or type of activity (e.g., sports, arts, clubs). This article questions the ecological validity of this approach. Youth often have multiple interests and options for engagement in activities over 
the course of a school year. Moreover, year to year, options change to accommodate the biological, psychological, and social changes occurring for youth. Using data from the 4-H Study of Positive Youth Development, this article describes the nature of after school activity participation among young adolescents (fifth and sixth graders), and discusses the implications of the participation patterns for the conduct and evaluation of youth development programs.

\section{The 4-H Study of Positive Youth Development}

Begun in 2002-2003 by studying fifth graders from 13 states, the 4-H Study of Positive Youth Development is a longitudinal study of youth from across the United States. The study is predicated on a developmental systems theoretical view of the process of human development, one involving bidirectional, mutually influential relations between individuals and their contexts.

Three key hypotheses guide the study:

1. Positive Youth Development (PYD) is constituted by the "Five Cs" of competence, confidence, connection, character, and caring, which are seen as a set of latent constructs summarizing the psychological, behavioral, and social relational variables linked to adolescent thriving, (Damon, 2004; Eccles \& Gootman, 2002; Lerner, 2004). An ancillary hypothesis to this first idea is that, when youth thrive, a sixth " $\mathrm{C}$ " emerges, that is, contribution to self, family, community, and civil society.

2. Across adolescence, PYD occurs when the strengths of young people are aligned with the strengths of their social, cultural, and physical ecologies; and

3. Youth Development (YD) programs constitute a key resource promoting PYD (Lerner, 2004). YD programs are defined as programs marked by the presence of three features of optimal youth programming -- positive adult-youth relations, skill building activities, and youth participation and leadership.

Given the core interest in Hypothesis 3 by colleagues involved with the design and delivery of youth programs, a major objective of the 4-H Study is to understand more about how youth spend their time after school. For instance, what is the configuration of youth after school activity participation? In addition to youth development program participation, in what other activities do youth engage? Does this configuration of after school activity participation remain the same or change across the early years of adolescence?

\section{After School Activities}

After school programs and activities vary in content and structure; yet, most share similar goals including providing a safe and supervised environment and opportunities for skill development across various domains (e.g., academic, social, physical). In general, researchers have documented beneficial effects for participation in organized out of school activities. For example, Scales, Benson, Leffert, and Blyth (2000) found that youth participation in sports, clubs, or organizations at school or in the community for three or more hours a week was the single developmental asset (of 40 total assets assessed) that was most linked to thriving outcomes among the adolescents.

The positive findings associated with after school activity participation has spurred an interest in what exactly produces this effect. As noted above, our hypothesis is that this relationship emerges due to the presence of the above-noted three features of optimal youth programming, i.e., what Lerner (2004) terms the "Big Three" components of effective youth development programs. These 
characteristics target youth's developmental needs and provide opportunities for growth. Reviews by Blum (2003), Eccles and Gootman (2002), Larson and Walker (2005), and Roth and BrooksGunn (2003) differ in the number of attributes they propose as important for the conduct of youth programs effective in promoting PYD. Nevertheless, all of these scholars agree on the importance of the "Big Three" as crucial for promoting exemplary positive development. It is these features that differentiate between youth programs and youth development programs. YD programs have an expressed adherence to a PYD perspective, which emphasizes the potential in every individual for positive, healthy growth across the life span. Instead of anticipating and trying to fix or prevent problems, the PYD approach considers ways to develop individuals and social contexts.

\section{Summary of Study Goals}

With such enormous expectations placed upon after school activity participation, and on YD program participation in particular, it is vital to understand the ecologically prototypic nature of youth engagement in these activities. If across the early years of adolescence, youth consistently spend a good deal of time in structured, after school activities, and if a major proportion of their time is allocated to YD programs, then the implications for program design and evaluation would be markedly different than if youth varied across time in their participation in one or more structured after school program activities and/or if they spent only a small proportion of their time in YD programs. The aim of the present report is to present longitudinal data about consistency and changes in youth participation in structured after school activities.

\section{Method}

The design and methodology of the 4-H Study has been presented in detail in Lerner, et al. (2005). We present here the features of the study associated with our interest in describing the nature of after school activity participation among participants.

\section{Participants.}

Data were collected on 983 youth in both Wave 1 and Wave 2 (females $=54.4 \%$; African American $=5.7 \%$; Asian American $=4.9 \%$; European American $=64.2 \%$; Latino $/$ a $=18.6 \%$; Multi-ethnic/racial $=3.6 \%$; Average household income $=\$ 54,000 ;$ Average mother's education $=$ 13.8 years). The demographic characteristics of the longitudinal sample are comparable to those of the overall fifth and sixth grade participants.

\section{Measure: The Youth Activity Survey.}

A youth activity survey was developed for inclusion in the Student Questionnaire used in the 4-H Study. Participation in 21 and 26 potential after school activities in Wave 1 and Wave 2, respectively, were assessed. The activity list includes structured activities (Wave $1=14$, Wave 2 $=19$ ), service activities, instruction, and paid work. The structured activities were categorized into four domain specific groupings: Youth development programs, sports, arts, and clubs. Youth development programs included the five major national youth serving organizations with an expressed PYD mission (4-H, YMCA, Boys and Girls Clubs, Scouts, and Big Brother/Big Sister). Sports participation was assessed with two questions (sports and martial arts). Five different art activities and lessons were asked at Wave 1 (school band, drama, dance, music, arts/crafts); three additional items were added at Wave 2 (drama club, school play, chorus). Finally, other after school clubs included two items (academic clubs and religious youth groups); two additional items were added at Wave 2 (school newspaper and hobby club). 
For each item, youth reported if they participated in each of the activities, during the current school year or summer, and the frequency of their participation. Data from the responses to the activities survey were scored in four ways:

1. Dichotomized Involvement: whether or not a youth reports being involved in an activity (Yes/No)

2. Intensity: amount of time youth participates in a program for a given period (hours/month)

3. Breadth: variety of participation (e.g., sports and arts)

4. Duration: history of participation (number of years in which the youth had participated in the activity)

The data presented in this paper use information regarding dichotomized involvement and breadth to describe profiles of participation.

\section{Results}

Table 1 displays the percentage of youth, by grade and gender, who participate in each of the four categories of activities. As can be seen, sports and arts attract the largest numbers of youth, with YD programs having the smallest percentage of youth. Girls are significantly more likely to participate in arts in Grade 5 and 6, and clubs in Grade 5, while boys are more likely to participate in sports in sixth grade. Boys' participation in sports increased across grades and their participation in arts activities decreased. Participation in clubs decreased for both boys and girls.

Table 1

Percentage of Youth Who Participate in Each Activity Type

\begin{tabular}{|l|c|c|c|}
\hline \multicolumn{5}{|c|}{$5^{\text {th }}$ Grade } \\
\hline & Total & Males & Females \\
\hline YD Programs & 39.3 & 39.2 & 39.7 \\
\hline Sports & 65.2 & 67 & 64 \\
\hline Arts & 68.8 & 61 & $75.5^{*}$ \\
\hline Clubs & 42.4 & 37.8 & $46.6^{*}$ \\
\hline \multicolumn{4}{|c|}{$6^{\text {th }}$ Grade } \\
\hline YD Programs & 35.4 & 33.3 & 37.1 \\
\hline Sports & 72.1 & 78.5 & $66.9^{*}$ \\
\hline Arts & 64.4 & 52.4 & $72.4^{*}$ \\
\hline Clubs & 26.5 & 24.2 & 28.4 \\
\hline
\end{tabular}

Note: Dichotomized participation $* \mathrm{p}<.05$

Given the high percentage of participation in each activity group, it is clear that youth are simultaneously participating in multiple activities.

Table 2 displays the percentage of youth participating in each combination of the four activity groups for Grades 5 and 6 . As shown in the table, only about $11 \%$ of the fifth grade and $8.5 \%$ of the sixth grade youth did not participate in any after-school activity. Of the remaining youth, only $19.9 \%$ of fifth graders and $25.5 \%$ of sixth graders participated in a single type of program and, of these youth, only $1.8 \% 5^{\text {th }}$ grade and $1.9 \% 6^{\text {th }}$ grade youth participated in a youth development program only. In fifth grade, the largest percentage of youth was involved in three different types 
of programs. However, between fifth and sixth grade, the most frequent profile of activity participation becomes two types of programs. In addition, single program participation increases, while youth participating in three or more types of programs decreases.

Table 2

Breadth of Structured After School Activity Participation During the $5^{\text {th }}$ and $6^{\text {th }}$ Grade Percentage of Youth Who Participate

\begin{tabular}{|c|c|c|}
\hline & $5^{\text {th }}$ Grade & $6^{\text {th }}$ Grade \\
\hline No Program & 11.0 & 8.5 \\
\hline Single Programs & 19.0 & 25.5 \\
\hline YD Program Only & 1.8 & 1.9 \\
\hline Sports Only & 6.9 & 13.6 \\
\hline Arts Only & 9.0 & 8.9 \\
\hline Clubs Only & 2.2 & 1.1 \\
\hline Two Types of Programs & 21.2 & 34.4 \\
\hline \begin{tabular}{l|l|} 
& YDP \& Sports \\
\end{tabular} & 3.5 & 5.6 \\
\hline YDP \& Arts & 2.9 & 3.0 \\
\hline YDP \& Clubs & 0.7 & 0.7 \\
\hline Sports \& Arts & 11.7 & 20.0 \\
\hline Sports \& Clubs & 2.4 & 3.0 \\
\hline Arts \& Clubs & 5.0 & 2.1 \\
\hline $\begin{array}{l}\text { Three Types of } \\
\text { Programs }\end{array}$ & 28.3 & 23.3 \\
\hline \begin{tabular}{l|l} 
& YDP, Sports, Arts \\
\end{tabular} & 10.8 & 12.1 \\
\hline YDP, Sports, Clubs & 2.7 & 2.0 \\
\hline YDP, Arts, Clubs & 2.3 & 1.7 \\
\hline Sports, Arts, Clubs & 12.5 & 7.5 \\
\hline All Four Types & 14.7 & 8.3 \\
\hline
\end{tabular}

Note: Dichotomized Participation

The percentage of sixth grade youth whose profile of participation changed from what it had been in fifth grade is shown in Table 3. As shown in the table, most youth change their profile of program participation across these two grades. For instance, $94.1 \%$ of fifth graders who were only in a YD program changed their profile in sixth grade. 
Table 3

Change in Structured After School Activity Participation From the $5^{\text {th }}$ to $6^{\text {th }}$ Grade

Percentage of Youth Whose Participation Changed

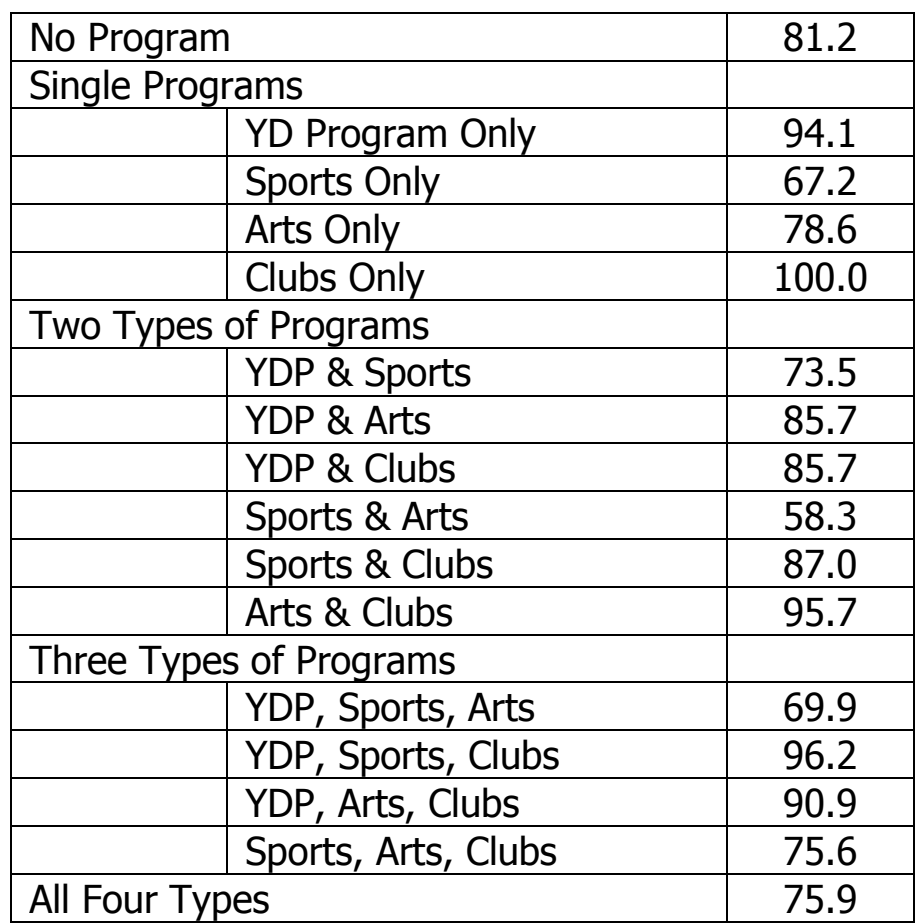

Note: Dichotomized Participation

\section{Discussion}

The purpose of this paper was to describe the configuration and changes in young adolescents' participation in structured after school activities in general, and in YD programs specifically. The findings are examined in regard to the implications for the design and evaluation of youth development programs. Knowledge of this ecology is critical if youth development programs are going to fulfill their theoretically specified task of being a key resource for youth in the promotion of their positive development (e.g., Eccles \& Gootman, 2002; Lerner, et al., 2005).

Longitudinal data from the first two waves of the 4-H Study of PYD indicate that YD programs not only have a competitive window for "hitting the target" (attaining the goal) of reaching youth to promote PYD but, as well, the target is a moving one! The data indicate that when a fifth grader participates in a youth development program (such as $4-\mathrm{H}$ ), the vast majority of the time, he or she is also participating in one or more other types of programs. Thus, independent of the distribution of hours allocated to the various types of programs, a parameter that complicates the potential impact of youth development programs is that they share youth time with other types of after school programs, and have to present their message of PYD within a potentially diverse cacophony of messages presented by other programs. These messages may or may not be congruent with the YD message or with the principles of programming associated with such programs.

The current findings suggest that participation in multiple types of activities is the most common profile and perhaps the most optimal, given the various interests and needs of youth. Youth need to be able to choose what interests them and have the opportunity to participate in effective, 
growth promoting programs irrespective of curriculum. Communities must provide a variety of different options for youth and youth can select themselves into activities of their choosing.

In addition to the breadth of youth participation at a single point in time, the profile of an individual's activities changes from year to year as youth interests and identity consolidate and their time gets taken up with other responsibilities including school and homework. This pattern of changes may be expected to increase as youth transition across middle school and high school and the school begins to be the primary mechanism for offering after school activities. Indeed, leaders in the youth development program field note that community-based organizations struggle to maintain enrollment during these critical years (Floyd \& McKenna, 2003).

Further, after school programs are embedded in unique social, cultural, and physical ecologies that impact individual motivation and engagement and provide different opportunities and resources for youth (Mahoney, Larson, \& Eccles, 2005; Noam, 2004; Simpkins, Ripke, Huston, \& Eccles, 2005). As such, we must recognize that the challenge for understanding the impact on PYD of after school activity participation generally, or YD programs specifically, is far more complex than perhaps articulated among practitioners, researchers, or program evaluators. Certainly, randomized control designs involving appraisals of the impact of a single YD program experienced alone during the course of one school grade seem inadequate and, in fact, inappropriate for evaluating the ecologically prototypic reality of YD programs either within or across time (Lerner, Dowling, \& Chaudhuri, 2005; McCall and Green 2004).

Youth naturally select themselves into different programs and participate in many activities making it difficult to determine which programs contributed to an effect. For the field to continue to answer key questions about the efficacy and impact of YD programs, multiple types of studies need to be conducted, including longitudinal development studies, case studies, and process evaluations. For example, one limitation of the current study is the classification of YD programs. Although each of the major national youth serving organizations expresses a PYD mission, this may not translate into program operations. Similarly, sports and arts programs were not classified as youth development programs, but indeed may also subscribe to a PYD mission and meet the developmental needs of youth. Future studies need to measure program features and assess if indeed the "Big Three" are present or absent.

In sum, the fifth and sixth graders participating in the 4-H Study engage in structured after school activities at a high level. Fewer than $12 \%$ do not participate in any activity. Participation in multiple activities is the norm for these youth and the configuration of activities changes between grades. The cacophony and change in the ecology of structured after school activity participation among adolescents suggests that youth development program professionals have complex challenges in attempting to recruit and retain youth into their programs, in working to promote PYD through their programs, and in trying to evaluate their efforts in ways that will be convincing to funders and policy makers. Moreover, given the breadth of youth activity participation, it will be important for youth to experience the "Big Three" features of effective YD programs in all programs they turn to for after school activities. As such, broad community collaboration in regard to youth programming is essential.

This research was supported in part by a grant from the National 4-H Council. Reprint requests may be sent to Richard M. Lerner, Institute for Applied Research in Youth Development, 301 Lincoln-Filene Building, Tufts University, 105 College Avenue, Medford, MA 02155 or by emailing richard.lerner@tufts.edu 


\section{References}

Blum, R.W. (2003). Positive youth development: A strategy for improving health. In. F. Jacobs, D. Wertlieb, \& R.M. Lerner (Eds.), Handbook of applied developmental science: Vol. 2 Promoting positive child, adolescent, and family development through research, policies, and programs (pp. 237-252). Thousand Oaks, CA: Sage Publications.

Cooper, H., Valentine, J.C., Nye, B., \& Lindsay, J.J. (1999). Relationship between five after-school activities and academic achievement. Journal of Educational Psychology, 91(2), 369-378.

Damon, W. (2004). What is positive youth development? The Annals of the American Academy, 591, 13-24.

Eccles, J.S., \& Barber, B.L (1999). Student council, volunteering, basketball or marching band: What kind of extracurricular involvement matters? Journal of Adolescent Research, 14 (1), 10-43.

Eccles, J., \& Gootman, J. (Eds). (2002). Community programs to promote youth development. Washington, D.C.: National Academy Press.

Floyd, D.T., \& McKenna, L. (2003). National youth serving organizations in the United States: Contributions to civil society. In R.M. Lerner, F. Jacobs, \& D. Wertlieb (Eds.), Handbook of applied developmental science: Promoting positive child, adolescent, and family development through research, policies, and programs: Vol. 3. Promoting positive youth and family development: Community systems, citizenship, and civil society. (pp. 11-26). Thousand Oaks, CA: Sage Publications.

Larson, R., \& Walker, K.C. (2005, April). Beyond program standards: Toward an understanding of practice. Paper presented at the Society for Research in Child Development, Atlanta, GA.

Lerner, R.M. (2004). Liberty: Thriving and civic engagement among American youth. Thousand Oaks, CA: Sage.

Lerner, R.M., Dowling, \& E. Chaudhuri, J. (2005). Methods of contextual assessment and assessing contextual methods: A developmental contextual perspective. In D.M. Teti (Ed.), Handbook of research methods in developmental science (pp. 183-209). Cambridge, MA: Blackwell.

Lerner, R.M., Lerner, J.V., Almerigi, J., Theokas, C., Phelps, E., Gestsdottir, S., \& et al. (2005). Positive youth development, participation in community youth development programs, and community contributions of fifth grade adolescents: Findings from the first wave of the 4-H Study of Positive Youth Development. Journal of Early Adolescence, 25, 17-71.

Mahoney, J.L., Larson, R.W., \& Eccles, J.S. (Eds.). (2005). Organized activities as contexts of development: Extracurricular activities, after school and community programs. Hillsdale, NJ: Lawrence Erlbaum Associates.

McCall, R.B., \& Green, B.L. (2004). Beyond the methodological gold standards of behavioral research: Considerations for practice and policy. Social Policy Report 18(2).

Noam, G. (Ed.) (2004). After-school worlds: Creating a new social space for development and learning. San Francisco: Jossey-Bass. 
Roth, J.L., \& Brooks-Gunn, J. (2003). What is a youth development program? Identification and defining principles. In. F. Jacobs, D. Wertlieb, \& R.M. Lerner (Eds.). Enhancing the life chances of youth and families: Public service systems and public policy perspectives. Volume 2 of Handbook of applied developmental science: Promoting positive child, adolescent, and family development through research, policies, and programs (pp. 197-223). Editors: Richard M. Lerner, Francine Jacobs, and Donald Wertlieb. Thousand Oaks, CA: Sage Publications.

Scales, P., Benson, P., Leffert, N., \& Blyth, D.A. (2000). The contribution of developmental assets to the prediction of thriving among adolescents. Applied Developmental Science, 4, 27-46.

Simpkins, S.D., Ripke, M., Huston, A.C., \& Eccles, J.S. (2005). Predicting participation and outcomes in out-of-school activities: Similarities and differences across social ecologies. In H.B. Weiss, P.M.D. Little, \& S.M. Bouffard (Eds.), New directions for youth development: Participation in youth programs: Enrollment, attendance, and engagement (Vol. 105; G. Noam, Series Ed., pp. 51-70). San Francisco: Jossey-Bass.

Youniss, J., \& Yates, M. (1997). Community service and social responsibility in youth. Chicago: University of Chicago Press.

(C) Copyright of Journal of Youth Development $~$ Bridging Research and Practice. Content may not be copied or emailed to multiple sites or posted to a listserv without copyright holder's express written permission. Contact Editor at: patricia.dawson@oregonstate.edu for details. However, users may print, download or email articles for individual use.

ISSN 2325-4009 (Print); ISSN 2325-4017 (Online) 